\title{
A sociedade escravista cubana e a Revolução Haitiana*
}

The Cuban Slave Society and the Haitian Revolution

\section{Ada Ferrer}

Professora no Departamento de História da Universidade de Nova lorque (New York University - New York / EUA) e Diretora do Centro de Estudos Latino-americanos e Caribenhos (University of Michigan - Ann Arbor/ EUA) e-mail:af6@nyu.edu

\section{Resumo}

0 texto estuda a repercussão da Revolução Haitiana em Cuba, entre fins do século XVIII e ao longo do século XIX. Analisa as diferentes formas de impacto do evento entre os senhores, os escravos e o Estado colonial.

\begin{abstract}
The text examines the impact of the Haitian Revolution in Cuba, between the late 18th century and throughout the 19th century. It analyzes the different forms of impact of the event among the slavemasters, slaves and the colonial state.
\end{abstract}

\section{Palavras-chave}

Revolução Haitiana, Cuba, escravidão

\section{Keywords}

Haitian Revolution, Cuba, slavery
Publicado originalmente em Annales: Histoire, Sciences Sociales, 58, n.2, 2003, p.333-356, com o título "La société esclavagiste cubaine et la révolution haïtienne". Tradução: Jaime Rodrigues. Revisão técnica: Lígia Fonseca Ferreira e Glaucia Ribeiro de Lima. As menções à Revolução Haitiana foram grafadas em maiúsculas, como quando fazemos referência a outros processos desse tipo - Revolução Inglesa, Revolução Francesa etc. (N. T.) 
Ver, em particular, TROUILLOT, Michel-Rolph. An Unthinkable History: The Haïtian Revolution as a Non-Event. In: Idem, Silencing the Past: Power and the Production of History. Boston: Beacon, 1995. p.70-107; BUCK-MORSS, Susan. Hegel and Haïti. Critical Inquiry, n.26, p.821-867, 2000; e GEGGUS, David Patrick. Haitian Revolutionary Studies. Boomington: Indiana University Press, 2002. p.157-158.

Ver HOBSBAWM, Eric. The Age of Revolution, 1789-1848. New York: New American Library, 1964; GODECHOT, Jacques. France and the Atlantic Revolution of the Eighteenth Century. New York: Free Press, 1965; FURET, François e OZOUF, Mona. Dictionnaire critique de la Révolution française. Paris: Flammarion, 1988, que não contém entradas para Haiti, SaintDomingue, escravidão, Caraibas ou colônias.

**

Saint-Domingue era a porção ocidental e francesa - atual Haiti - da ilha; Santo Domingo era a porção oriental e espanhola - atual República Dominicana. Ambas a s nomenclaturas aparecerão ao longo do texto (N. T.).

TROUILLOT, Michel-Rolph. Op. Cit., p.71.

Tratei desta tendência na Cuba de fins do século XIX (FERRER, Ada. Insurgent Cuba: Race, Nation, and Revolution, 1868-1898. Chapel Hill: University of North Carolina Press, 1999).
Duas abordagens da Revolução Haitiana, aparentemente contraditórias, prevaleceram desde o início do levante de escravos, em agosto de 1791. A primeira tende a negligenciar, subestimar ou deixar passar em silêncio esta revolução e seu impacto. Elas refletem as primeiras reações aos acontecimentos sangrentos daquele mês de agosto e as interpretações que surgiram ali. Confrontados com uma revolução liderada por homens e mulheres escravos que vieram para destruir as principais instituições da sociedade, os contemporâneos foram incapazes de enxergar a possibilidade de uma revolução conduzida por escravos e, mais ainda, uma revolução bem sucedida, levando à criação de um estado independente. Eles observaram e apreenderam os fatos através de categorias pré-concebidas, explicaram os eventos e deram uma interpretação, negando a possibilidade de que os escravizados pudessem fazer uma revolução. Suas explicações incriminaram os agitadores externos, os efeitos perniciosos da ideologia da Revolução Francesa, os erros de cálculo dos proprietários de escravos, mas quase nunca a vontade, a capacidade ou a consciência dos próprios escravos.

Esta falta de compreensão por parte dos contemporâneos marcou até a maneira como os historiadores lidaram com o tema ou então ficaram em silêncio. Como sustentou Michel-Rolph Trouillot, a incapacidade inicial de pensar dentro de categorias apropriadas pôs em xeque a narrativa histórica ao remetê-la à visão dos contemporâneos, fazendo da Revolução Haitiana uma ausência relativa na história'. Até mesmo as obras clássicas de Eric Hobsbawm e Jacques Godechot, ou mesmo os dicionários históri$\cos$ da Revolução Francesa, apenas mencionam a revolução dos escravos em Saint-Domingue ${ }^{2 * *}$. Eles têm sobre 0 evento um mesmo olhar, que 0 deixa sob uma relativa obscuridade. Sem precedentes ou equivalentes em sua contestação à escravidão e ao colonialismo, radical em seus efeitos, a Revolução Haitiana ainda é pouco conhecida, apesar do interesse que vem despertando nas últimas décadas, bem merecendo ser qualificada de tema "esquecido pela revolução mundial" ${ }^{3}$, como fez Trouillot recentemente.

A segunda abordagem parece, a princípio, exatamente o oposto. Porque se a incompreensão e o silêncio acompanharam e se seguiram a essa revolução, de 1791 até o século XIX a referência ao Haiti foi constante em todas as sociedades escravistas do Novo Mundo. Isso posto, falava-se sobre ela, se escreveu a respeito dela, todos os que eram capazes ou não de reconhecer nela uma revolução de escravos expressavam sua opinião. As notícias circularam, à época, entre os escravos e seus proprietários, enquanto as autoridades coloniais tentavam afastar dos seus territórios os escravos "contaminados" e as ideias sediciosas. Muitas décadas depois, a simples menção ao Haiti ainda mantinha um poder evocativo. No mundo atlântico, os rumores de revoltas de escravos que ameaçavam a estabilidade política automaticamente eram acompanhados por uma referência ao Haiti. Em tais circunstâncias, entre autoridades, intelectuais e proprietários de escravos falava-se da iminência de "um outro Haiti", e do desejo dos negros. ${ }^{4} 0$ Haiti desafiava a imaginação, mas falava-se sobre ele.

As constantes referências a isso muitas vezes consistiam apenas em insinuações e afirmações breves, sem conteúdo explícito. Mas, por mais imprecisas que fossem, essas referências poderiam evocar imagens concretas que esclarecessem ou ilustrassem uma opinião. Assim, com base na incompreensão ou no inconcebivel, como Trouillot observa, é possivel formular outra questão: como pode algo tão mal compreendido motivar tantas observações e tornar-se um assunto de predileção? 
Ver DUBOIS, William Edward B. The Suppression of the African Slave-Trade to the United States of America, 1638-1870. Nova York: Social Science Press, 1954, cap.07; GENOVESE, Eugene. From Rebellion to Revolution: Afro-American Slave Revolts in the Making of the Modern World. Baton Rouge: Louisiana State University Press, 1979. p.113-114; HUNT, Alfred N. Haiti's Influence on Antebellum America: Slumbering Volcano in the Caribbean. Baton Rouge: Louisiana State University Press, 1988. p.109-110.

6

Ver AIMES, Hubert. A History of Slavery in Cuba 1511-1868. New York: Octagon Books, 1967, e MURRAY, David. Odious Commerce: Britain, Spain, and the Abolition of the Slave Trade to Cuba. Cambridge: Cambridge University Press, 1980, cap.01.

7

0 argumento sobre a relação entre a Revolução Haitiana e a continuação do domínio espanhol em Cuba é dominante. Por exemplo, ver KUETHE, Allan J. Cuba, 1753-1815: Crown, Military and Society. Knoxville: University of Tennessee Press, 1986; IBARRA, Jorge. Ideología mambisa. Havana: Instituto Cubano del Libro, 1967; FRAGINALS, Manuel Moreno. España/Cuba, Cuba/España. Barcelona: Editorial Crítica, 1995; e PÉREZ, Louis A. Cuba Between Reform and Revolution. Nova York: Oxford University Press, 1988.

8

Ver LYNCH, John. The Origins of Spanish American Independence. In: BETHELL, Leslie (ed.). The Independence of Latin America. Oxford: Oxford University Press, 1987. p.47; LYNCH, John. The Spanish American Revolutions, 1808-1826. Nova York: Norton 1986, cap.06; e IZARD, Miguel. El miedo a la revolución: la lucha por la libertad en Venezuela (1770-1830). Madri: Editorial Tecnos, 1979
Como os contemporâneos do século XIX, que fizeram menções vagas ao Haiti, os historiadores apresentam a ilha - principalmente o medo que sua revolução inspira - de modo a explicar uma escolha histórica. Mas este recurso equivocado serviu para justificar conclusões muito divergentes. Assim, no caso dos Estados Unidos, os historiadores têm argumentado que o medo causado pela revolução do Haiti ajudou a acabar com o comércio de escravos para aquele país ${ }^{5}$, enquanto que para Cuba, insiste-se que, apesar do medo, a revolução levou a um aumento do tráfico negreiro. ${ }^{6} \mathrm{Na}$ experiência cubana, a hipótese invariável e constante é que o medo do Haiti levou a elite crioula a evitar a ideia de independência numa época em que quase todas as colônias espanholas se emancipavam de sua métropole.? Para a Venezuela, ao contrário, alguns historiadores têm mostrado que o medo de um "outro Haiti" incitou as elites a realizar um movimento de independência para evitar que escravos e negros livres se rebelassem, como no Haiti. ${ }^{8}$ A mesma crença e a mesma causa parecem produzir efeitos contrários. Nestes exemplos, a causalidade não é realmente explícita e supõe que o conteúdo e o significado do Haiti são tão óbvios que a invocação do "medo da Revolução Haitiana" é percebida como uma mensagem muito clara, chamando a atenção dos leitores e dizendo a eles que não é necessário desenvolver ou analisar os fatos. A mera menção ao Haiti ocupa o lugar de uma explicação. Invocar o medo da Revolução Haitiana era encorajar os leitores a aderir e concordar com esse entendimento.

Este artigo procura abrir o arquivo do "medo do Haiti" e questionar o modo como a Revolução Haitiana foi apreendida. Em vez de usar esse medo ou a idéia de Haiti para explicar a história, buscamos esclarecer suas numerosas instrumentalizações: os objetivos, a natureza, os efeitos do uso sistemático de referências e imagens de uma revolução negra ou um conflito de raças por uma ampla gama de atores sociais, os escravos e seus senhores e os altos funcionários coloniais. Através dessa menção e invocação constantes, o Haiti tornou-se uma representação que só correspondia parcialmente à realidade dos acontecimentos. Simplesmente mencionar ou ouvir o nome do Haiti no Atlântico durante a era revolucionária implicava em se referir a uma vasta gama de possibilidades: revolução, violência, extermínio, vingança, liberdade. Traçar alguns dos processos que levaram o Haiti a se tornar uma referência tão poderosa e polissêmica é entender como a evocação funcionava como uma chave pela qual todos os tipos de ordens ou desordens poderiam fazer sentido. Serão destacadas as maneiras pelas quais as recorrências a esse símbolo influenciaram a experiência dos escravos na sociedade colonial.

\section{Cuba: o medo, a escravidão e o Estado colonial}

Se os efeitos da Revolução Haitiana e as constantes referências à sua existência foram sentidos em todo o mundo americano, Cuba, no século $X I X$, oferece uma base fecunda para empreender esta análise. Ali tinha-se pleno conhecimento da revolução. De fato, o ponto mais a leste da ilha ficava a apenas oitenta quilômetros do Haiti. Proprietários e seus escravos chegaram aos milhares da colônia francesa em busca de refúgio, falando da vingança e da destruição perpetradas pelos negros. Durante as décadas seguintes à independência do Haiti, na parte leste do território, pouco povoada, houve temores e rumores contínuos de iminente invasão haitiana. Em Cuba, a Revolução Haitiana, portanto, foi sentida como uma ameaça premente. No entanto, esse perigo iminente vinha não só da proximidade 
Deve ser enfatizado que os fazendeiros cubanos criaram uma nova Saint-Domingue em um contexto muito diferente do que havia permitido o surgimento da colônia francesa. 0 boom em Cuba no início do século XIX ocorreu quando o comércio de escravos e a escravidão em si foram desafiados pela Revolução Haitiana e contestados pelo desenvolvimento dos movimentos abolicionistas ingleses. Isso favoreceu e, paradoxalmente, reviveu a escravidão em novos territórios, como Cuba, a ponto de às vezes ser chamado de "segunda escravidão". Ver TOMICH, Dale. Spaces of Slavery, Times of Freedom: Rethinking Caribbean History. World Perspectives: Comparative Studies of South Asia, Africa and the Middle East, n.57, p.67-80, 1997 e Idem. The Second Slavery: Bonded Labor and the Transformation of the Nineteenth-Century World Economy. In: RAMÍREZ, Francisco 0. Rethinking the Nineteenth Century: Contradictions and Movement. Nova York: Greenwood Press, 1998. p.103-117.

10

Ver, por exemplo, Ignacio Leyte Vidal à Juan Bautista Vaillant, Baracoa (28 de agosto de 1791), em "Documentos referentes a la sublevación de negros esclavos en la isla de Santo Domingo" (Archivo Nacional de Cuba [ANC], Fondo Asuntos Políticos [AP], leg.4, exp.33); Minuta, Muy reservada, al Exmo. Sr. Conde de Floridablanca (7 de setembro de 1791), ANC, Correspondencia de los Capitanes Generales [CCG], leg.42, exp.5; Manuel Gonzáles a Juan Bautista Vaillant, Kingston, Jamaica (13 de dezembro de 1791), ANC, CCG, leg.42, exp.8. Os dois últimos foram publicados em FRANCO, José Luciano. Documentos para la historia de Haití en el Archivo Nacional, Havana, ANC, 1954, p.64-70. A questão de saber quando um público mais amplo tomou conhecimento da rebelião tem resposta menos segura. A cobertura da mídia, através dos jornais espanhóis que circulavam em Havana, começou em novembro de 1791. Uma menção intrigante e pouco clara nos debates do cabildo de Havana atribui a falta de carne de porco a uma revolta dos negros que pode estar relacionada com os eventos em Saint-Domingue (Actas Capitulares del Ayuntamiento de la Habana transuntadas de Enero 1791 a Diciembre 1791 (9 de setembro de 1791), Archivo del Museo de la Ciudad de La Habana [AMCH], 1791, f.247).

11

Vizieu de Sombrages ao governador. D. Juan Bautista Vaillant, San Luis de Geremías (1 de novembro de 1791), em "Traducción de dos cartas fechadas 1 nov. 1791 referentes a la rebelión en Santo Domingo" (ANC, AP, leg.4, exp.35). 0 esquema usado pelos observadores que começaram a descrever cenas de rebelião ou invasão e que depois foi modificado, invocava a natureza horrivel ou inacreditável dos eventos, e continuou ao longo de décadas após a revolução. 0 autor ou orador interrompia sua descrição sob o pretexto de que o público seria capaz, por si só, de imaginar tais horrores, recorrendo à sua imaginação.

12

Conde de Floridablanca al Sr. Governador de Cuba, San Lorenzo (26 de novembro de 1791), ANC, CCG, leg.42, exp.7. Muitas dessas medidas estão reproduzidas em FRANCO, José Luciano. Documentos para la historia de Haití ..., Op. Cit. geográfica ou das rotas de migração, mas também do fato de que Cuba, em certo sentido, suplantava o Haiti. Na produção açucareira, Cuba chegou a ocupar o lugar que anteriormente era da francesa Saint-Domingue. ${ }^{9}$ Os fazendeiros cubanos, os comerciantes e os burocratas estavam plenamente conscientes disso, e viram-se seguindo os passos e às vezes suplantando seus homólogos franceses na outrora próspera Saint-Domingue. Um dos efeitos imediatos da revolução sobre esta ilha foi, portanto, a importação de um número cada vez maior de escravos provenientes da África para trabalhar nas plantações de cana de açúcar que tornavam Cuba a mais rentável das colônias. A Revolução Haitiana teve, assim, dois efeitos aparentemente contraditórios: encarnou a liberdade e o poder dos negros, embora tenha causado um incremento considerável da escravidão.

As notícias da eclosão da revolta de escravos em Saint-Domingue chegaram poucos dias depois que os escravos do norte rebelaram-se nas plantações. Autoridades no leste de Cuba, próximas da cena do levante, foram informadas pelos agentes que mantinham na colônia francesa e, em seguida, avisaram seus superiores em Havana e Madrid. Ecoando, ou talvez anunciando o que M. R. Trouillot reconheceu como a interpretação padrão dessa revolução, essas autoridades salientaram que os escravos eram liderados por estrangeiros, pelos brancos e, talvez, pelos "livre de cor".10 Os agentes descreveram a devastação em detalhes: as montanhas de cinzas, os negros bárbaros, as lágrimas dos brancos e o cativeiro das mulheres brancas que, tendo testemunhado o assassinato de seus maridos, foram presas e usadas conforme a vontade dos rebeldes negros. Terminada a primeira fase, violenta, da revolta, em novembro de 1791, um funcionário francês evocou "todas as coisas estranhas e incriveis que tinham acontecido nesse lugar", duvidando que os filhos de seus correspondentes espanhóis pudessem acreditar nele ${ }^{11}$.

0 Estado colonial respondeu imediatamente e de modo muito semeIhante ao da maioria dos Estados americanos. Assim como ocorreu após o início da Revolução na França, foram estabelecidas restrições à entrada de escravos e de franceses, antes de endurecer estas últimas com o início da revolução em Saint-Domingue. Os funcionários do Estado colonial falavam em conter o "contágio", "o mau exemplo" e "a atração" da rebelião e da liberdade, chamando a atenção para as constantes ameaças representadas por escravos estrangeiros ou pessoas livres de cor, e sobre os perigosos projetos de nações e impérios inimigos. Tudo isso expressava a necessidade de redobrar a vigilância. ${ }^{12}$ Os esforços e a prudência desses homens indicam o aumento do medo provocado pela revolução no espírito dos colonos. Mas seria errado afirmar que a revolução suscitou somente medo e terror entre brancos, fazendeiros e funcionários do Estado. Mesmo se fosse assim, tal medo deve ser visto como uma construção social, dependente de certas formas de conhecimento e de ignorância, uma espécie de "sociologia intuitiva", na qual as modalidades e os protagonistas da ação são apreendidos sem referência aos atores reais ou aos eventos. ${ }^{13}$

Que a resposta das elites se situa além do medo é algo patente. Apesar dos esforços feitos para se proteger das conseqüências da Revolução Haitiana, e apesar das reações de ansiedade que a revolução dos escravos poderia gerar em Cuba, isso não impediu o Estado colonial e os fazendeiros cubanos de imitar precisamente a sociedade escravista que havia provocado os acontecimentos que eles rejeitavam. De fato, as informações sobre a revolta de escravos em Saint-Domingue chegaram quando as autoridades e 
Para um debate sobre a resposta dos Estados escravistas coloniais do Atlântico à revolução, ver SCOT, Julius S. The Common Wind: Currents of Afro-American Communication in the Era of the Haitian Revolution. Ph.D., Duke University, 1986; HUNT, Alfred N. Op Cit., e FRANCO, José Luciano. Revoluciones y conflictos internacionales en el Caribe, 1789-1854. Havana: Academia de Ciencias, 1965, em particular os capítulos 1 a 4 . 13

A expressão "sociologia intuitiva" é emprestada de FARGE, Arlette e REVEL, Jacques. The Vanishing Children of Paris: Rumors and Politics before the French Revolution. Cambridge: Harvard University Press, 1991. p.53.

14

Francisco Arango y Parreño, em nome do Ayuntamiento de Havana, havia solicitado a concessão, por três anos, para que espanhóis e estrangeiros introduzissem escravos africanos em Cuba. A "Real Cédula" de 28 de fevereiro de 1789 concedeu a solicitação por dois anos. Em agosto de 1791, Arango pediu uma extensão dessa licença. Informações vindas do Haiti chegaram aos ouvidos das autoridades espanholas quando a revisão do pedido ainda estava pendente. Arango o reiterou em novembro, e uma extensão de seis anos foi concedida, a partir de 1 de janeiro de 1792. Ver ARANGO Y PARREÑO, Francisco. Representación hecha a S. M. con motivo de la sublevación de esclavos en los dominios franceses de la Isla de Santo Domingo (20 de novembro de 1791). In: Obras. La Habana: Dirección de Cultura, 1952, I, p.111-112; e AIMES, Hubert. 0p. Cit., p.48-50. Para um debate sobre Arango, a "plantocracia" e sua noção de desenvolvimento econômico depois da Revolução Haitiana, ver TOMICH, Dale. The Wealth of Empire: Francisco Arango y Parreño, Political Economy, and the Second Slavery in Cuba. Comparative Studies in Society and History, n.1, p.4-28, 2003.

15

ARANGO Y PARREÑO, Francisco. Representación hecha a S. M... Op. Cit, Tomo.1, p.111-112.

16

Ibidem, p.107.

17

Sobre a migração de Saint-Domingue para Cuba, ver DUHARTE, Rafael. La huella francesa en Santiago de Cuba. Paris: L'Harmattan, 1988. Sobre as restrições de entrada ou de residência de escravos vindos de Saint-Domingue, ver FRANCO, José Luciano. Documentos para la historia de Haití ...., Op. Cit.

18

KIPLE, Keneth. Blacks in Colonial Cuba, 1774-1899. Gainesville: University Press of Florida, 1976. p.2728 e p.38. 0 autor discute as diferentes estimativas da população e os dados dos recenseamentos, e aceita os números de Ramón de la Sagra para 1774 e 1792. Para 1817, ele se baseia no censo oficial da administração espanhola. os fazendeiros aguardavam a resposta do rei e do Conselho das Índias sobre a ampliação e a duração do comércio de escravos para Cuba. Os fazendeiros crioulos tinham enviado uma petição pedindo a abertura e liberação do tráfico, para que as importações de africanos se tornassem mais rápidas e de maior volume, a fim de apoiar o crescimento da agricultura e da economia. ${ }^{14}$ Temendo que os eventos em Saint-Domingue encorajassem o rei a restringir o tráfico de negros, fazendeiros e autoridades insistiram no fato de que não haveria nenhum risco a temer. Em uma de suas primeiras declarações sobre os efeitos da Revolução Haitiana, em novembro de 1791, Francisco Arango y Parreño, pensador e político cubano, escreveu que considerava os eventos em Saint-Domingue "não só com compaixão para com os franceses, mas também de uma perspectiva política, e anunciava, como bom patriota e vassalo (...) a oportunidade de dar à nossa agricultura uma nítida vantagem sobre os franceses" ${ }^{\prime 15}$. Ele advogou pela liberalização e pelo desenvolvimento do tráfico negreiro em Cuba. Ao propor o aumento do número de escravos, enquanto as informações sobre a revolução e as devastações em Saint-Domingue se espalhavam pelo território, os fazendeiros que, de acordo com seu status, também ocupavam posições de destaque no Estado colonial, afirmavam que era infundado o temor de uma rebelião devido ao incremento do comércio negreiro. 0 que aconteceu em Saint-Domingue não aconteceria em Cuba. Em primeiro lugar, insistiam eles, os homens livres de cor eram súditos leais da Coroa espanhola, e os escravos cubanos, ao contrário dos escravos franceses, eram dóceis e bem tratados por seus senhores e pela lei espanhola. Seus congêneres franceses rebelaram-se porque os franceses thes deram o exemplo: "Uma desordem causada por outra. Os senhores instruíram seus escravos e participaram de sua própria ruína". Como os escravos do lugar não causaram nenhuma preocupação, os traficantes de africanos não tiraram mais vantagens daquela situação. Arango afirmou que eles estavam mais preocupados com sua carga humana e com seus lucros do que com a revolução ou as intrigas imperiais. A Espanha devia preocupar-se menos com os africanos recentemente escravizados e transportados para o Novo Mundo. Ele explicou ao rei: "E as costas da África? Que notícias ou idéias de agitação podem vir dali? Esses corações de pedra, esses homens (...) que fazem um comércio lamentável de seus próprios irmãos são os únicos que devemos temer" ${ }^{16}$.

Confrontado com a perspectiva quase certa da chegada de milhares de africanos para apoiar o crescimento da indústria açucareira e com uma sociedade traumatizada no leste da ilha, fazendeiros-estadistas se recusaram a ter medo. 0 Estado proibiu a entrada de escravos franceses, mas quis acolher os fazendeiros franceses, na esperança de que eles estimulassem a agricultura comercial. Os funcionários locais, sabendo que tinham que expulsar esses escravos, simplesmente explicaram que não tinham como fazer isso. Outros dirigentes fizeram os escravos vindos de Saint-Domingue assinarem declarações de lealdade, obrigando-os a negar que tivessem participado dos terriveis levantes de Guarico - o nome dado pelos espanhóis à parte francesa de Saint-Domingue ${ }^{17}$. As autoridades e os fazendeiros toleraram os escravos supostamente vindos da revolta e aguardavam impacientes a chegada de novos braços provenientes das costas africanas. De sorte que, nas duas décadas após a independência haitiana, a população escrava de Cuba registrou um crescimento sem precedentes: entre $1774 \mathrm{e}$ 1817, a população negra mais do que quadruplicou, passando de 75.180 (ou de $43,8 \%$ da população) a 339.179 (ou $58,6 \%$ ). ${ }^{18}$ 
19

Os defensores de um comércio de escravos mais regulamentado argumentavam que os franceses, em 1781, em um momento em que "a colônia de Guarico estava em uma situação similar à nossa situação atual", permitiram a importação de negros em navios de países inimigos se eles usassem uma bandeira neutra. A partir desse precedente, eles concluiram que as autoridades espanholas dariam permissão semelhante para Cuba. Consulte "Accuerdo de la Junta de Gobierno del Real Consulado" (18 de outubro de 1797), e Juan Toma's de Jaurrequí ao capitão general (23 de outubro de 1797), em "Expediente relativo a las precauciones y seguridad en orden a los negros en general y en particular a los introducidos de las colonias extranjeras", ANC, Real Consulado y Junta de Fomento [RCJF], leg.209, exp.8993; ver também Memorias de la Sociedad Patriótica de la Habana, 1793, p.13-14 e p.36-38.

20

Sobre os recenseamentos em Cuba no século XIX, consulte KIPLE, Keneth. Op. Cit., e a obra do "primeiro demógrafo" de Cuba, HERNÁNDEZ, Antonio del Valle. Sucinta noticia de la situación presente de esta colonia, 1800, com uma introdução de Juan Pérez de la Riva. Havana: Editorial de Ciencias Sociales, 1977. Para uma discussão sobre as ligações entre a formação do Estado e as estatísticas no contexto colonial, ver APPADURAI, Arjun. Number in the Colonial Imagination. In: Idem. Modernity at Large: Cultural Dimensions of Globalization. Minneapolis: University of Minnesota Press, 1996. p.114-135; e ANDERSON, Benedict. Census, Map, Museum. In: Idem. Imagined Communities: Reflections on the Origin and Spread of Nationalism. Londres/Nova York: Verso, [1983] 1991. p.163-185.

21

"Memorias de la Real Sociedad Patriótica de la Habana", 1794, manuscrito. Havana: Instituto de Literatura y Linguística.
A reação dos cubanos notáveis, crioulos e espanhóis, em relação à revolução dos escravos resultou, então, menos do medo de que de um cálculo. Observando o colapso da outrora próspera colônia de Saint-Domingue, eles tentaram preencher o vazio, importando um número crescente de escravos e acumulando mais riquezas graças às plantações de cana-de-açúcar. A revolução poderia fazê-los progredir, e enquanto os franceses brancos perdiam suas vidas, suas propriedades e seu território, os cubanos continuaram a defender sua linha de ação, recomendando de forma explícita e vívida que se fizessem em Cuba o que os franceses tinham feito em Saint-Domingue. ${ }^{19}$ Em suma, eles tentaram tornar-se o que o Haiti já fora, reproduzindo uma sociedade próspera, baseada no açúcar, na escravidão e no colonialismo, na esperança de conseguir impedir que essas mesmas instituições reproduzissem o que tinha ocorrido em Saint-Domingue. Assim, o impacto da Revolução Haitiana em Cuba não pode ser entendido por meio de referências ao medo ou terror. De fato, o impacto do levante teve efeitos contraditórios em Cuba: ao mesmo tempo em que criou uma maior consciência e um medo de rebelião e do poder dos escravos, levou a um grande aumento no número destes, a um novo estatuto de "minoria" para brancos e a um crescimento econômico calcado no modelo de Saint-Domingue.

Mas os cálculos e suposições não cegaram os fazendeiros nem 0 Estado. A partir de relatórios e consultas sobre a melhor formar de manter um equilibrio entre o lucro e a sobrevivência, eles tomaram suas decisões, salientando a diferença entre Cuba e Saint-Domingue e afirmando que não era preciso ter medo de fazer de Cuba uma sociedade escravista. A abordagem deles teve dois objetivos. De um lado, a observação de possiveis ameaças externas vindas dos Estados europeus rivais e, cada vez mais, do próprio Haiti; de outro lado, o monitoramento criterioso de seu próprio território. De fato, o exemplo haitiano levou a elite dos senhores de escravos e os funcionários coloniais a ter um olhar diferente sobre sociedade local e sua própria população, seu território e suas relações sociais em função da imagem que eles tinham do Haiti. Dessa forma, pode se detectar a tomada de consciência que a Revolução Haitiana poderia migrar para a grande ilha vizinha. 0 interesse aqui é menos oferecer evidências de medo ou refutar a existência dele entre as elites cubana e espanhola do que explorar as formas pelas quais os desdobramentos quase simultâneos da revolução escrava no Haiti e da rápida progressão da escravidão foram afetados pelos esquemas de compreensão da sociedade e do poder.

0 desejo de fazer de Cuba uma sociedade escravista depois dos acontecimentos do Haiti levou a uma nova preocupação com a demografia e à convicção de que a segurança necessitava de um recenseamento constante das raças que formavam a população da ilha ${ }^{20}$. Os primeiros ecos da Revolução Haitiana em Cuba assinalaram o desequilibrio numérico entre os negros rebeldes e as forças européias encarregadas de combatê-los. Discutindo o aumento do tráfico de negros no mesmo momento em que transcorria a revolta haitiana, Arango e outros reconheceram que 0 comércio devia crescer, mas que o Estado devia prestar atenção à divisão numérica da população insular. Ainda que a Real Sociedad Patriótica de La Habana declarasse que apesar da introdução de negros dever ser encorajada para favorecer o desenvolvimento da ilha, [ela] deve ser acompanhada de um recenseamento constante, não sendo jamais autorizado que o número de negros exceda, ou iguale, o dos brancos"21. Eles preconizavam um aumento da imigração de brancos e insistiam na necessidade de 


\section{2}

"Acta de Cabildo de la Habana sobre como aumentar la población blanca". BNJM, CM Morales, t.80, n.13.

23

Ver a introdução de Juan Pérez de la Riva ao livro de HERNÁNDEZ, A. del Valle. Op. Cit., p.10-11. Consulte: "Expediente sobre las noticias comunicadas por el Sr. Sindico Don Francisco Arango y Parreño adquiridas en el viage que por encargo de S. M. ha hecho a Ynglaterra, Portugal, Barbada y Jamayca 1795" (ANC, RCJF, leg.92, exp.3923).

24

"Real Consulado. Copia del Expediente n.134 sobre proponer al Rey un plan para asegurar la tranquilidad y obediencia de sus servios de esta Colonia en Representación de 10 de Julio de 1799" (Expediente sobre el fomento de la población blanca en esta Ysla, ANC, RCJF, leg.184, exp.8330). Ver também Sebastian Kindelá ao capitão general Someruelos, na sequência da carta de 7 de março de 1804 (Archivo General de Indias [AGI], Cuba, leg.1549).

Marrón ou cimarrón eram termos usados em partes da América espanhola para se referir a escravos fugidos. Tratava-se de uma analogia com animais domésticos que, fugidos, tornavam-se novamente selvagens nas matas ( $\mathrm{N}$. T.). equilibrar o crescimento do número de negros com a vinda de brancos. Em 1815, o Cabildo de Havana ecoou os argumentos a favor da imigração branca a fim de "reduzir os temores despertados pela vertiginosa propagação de escravos e livres de cor, que infestam nossas cidades e nosso campo". Ressaltou-se que a população negra continuava a crescer mais rapidamente que a população branca, e já havia ultrapassado esta última. De fato, os membros do Cabildo notaram que "depois de muito tempo de equilibrio, há agora dois batismos de pessoas de cor para um batismo de branco". Os membros do Cabildo sustentavam a idéia de que tais números, associada com a proximidade em relação ao Haiti (e a líderes como Henri Christophe, "que chama a si mesmo de rei do Haiti"), significava que "os leais moradores de Cuba estavam cercados por todos os lados pelo mal que ameaçava sua existência e tranquilidade" ${ }^{\prime 2}$. Reconhecendo que a prosperidade de Cuba em matéria de agricultura e comércio devia-se ao declínio de Saint-Domingue e ao recente aumento da escravidão, o Cabildo e outras autoridades simplesmente insistiram no dever de promover a imigração de brancos e fazer censos populacionais regularmente.

$\mathrm{Na}$ verdade, o duplo desejo de ter acesso à força de trabalho negra e garantir a supremacia branca levou a numerosas tentativas de contar e classificar a população cubana. Assim, o projeto de um Estado colonial foi construido com base no contexto posterior à Revolução Haitiana. ${ }^{23}$ No leste de Cuba, a preocupação do Estado com a demografia foi diferente. Nessa região, geograficamente mais próxima do Haiti, o Estado lamentou a falta de população. Os funcionários da ilha evocaram as milhas de costa desabitada e a proximidade de um Haiti cada vez mais poderoso. Esses dois fatos eram mais perigosos do que a existência de grandes comunidades de escravos fugidos e espalhados pelo território. As autoridades viam esses agrupamentos como uma das maiores ameaças à segurança da ilha. Não podemos dizer o que sabiam acerca da existência e do poder dos negros na Saint-Domingue colonial. Mas eles constatavam a existência, na Cuba pósRevolução Haitiana, de uma região oriental selvagem e desabitada, com escravos fugitivos gradativamente ocupando um território cada vez maior, que acreditavam estar fora dos limites de ação dos brancos e do Estado, mas os contrabandistas aventureiros haitianos poderiam descobrir essa região e instrui-los sobre os meios de fazer uma rebelião. Assim, nas áreas montanhosas e sob ameaça crescente, uma empresa formada por escravos africanos, ligados aos rebeldes haitianos, praticava incursões cada vez mais violentas às plantações e aos territórios espanhóis, chegando até a por em perigo a própria existência da colônia. "Que visão! Que conflito!", afirmou um funcionário em $1799 .{ }^{24} \mathrm{~A}$ gravidade do perigo causado por essas aldeias de negros marrons*** podia ser real ou exagerada, mas é claro que o exemplo do Haiti, numa época de incremento da importação de escravos, emprestou um novo poder simbólico a uma antiga instituição (a fuga de escravos). E a referência ao Haiti pode ter cedido lugar a certas exigências especificas (neste caso, obter um crescimento da população branca e monitorar a costa oriental) para conseguir maior soberania e eficiência. 0 terror pode ter sido verdadeiro, mas também foi útil em alguns aspectos, quando não era mais o medo de 1791, época em que o futuro do comércio de escravos foi questionado... Também está claro que, se a Revolução Haitiana (e o perigo que ela representava) pode ter incentivado os funcionários coloniais e as elites cubanas a considerar as questões demográficas e administrativas, ela também os encorajou a representar e governar Cuba 
"Gobernador Marqués de Someruelos instruye de las noticias que le ha dado el Gobernador de Cuba 1804" (Archivo Historico Nacional [AHN], Madrid, Estado, leg.6366, part.2, exp.87). "Kindelán a Someruelos, oficio n.1151" (AGI, Cuba, leg.1549); "Marqués de Somuerelos participa haber llegado alli dos ciudadanos franceses que saliéron de la Ysla de Santo Domingo con una comisión para Europa (12 de julio de 1800)" (AHN, Estado, leg.6366, exp.15).

26

Ver, por exemplo, os apelos à ajuda cubana feito pelos refugiados e residentes de Santo Domingo, conservados no Archivo del Ministerio de Asuntos Exteriores [AMAE], Política Exterior, República Dominicana, leg.2372; e RODRÍGUEZ Y DEMORIZI, Emilio. Invasiones haitianas de 1801, 1805, y 1822. Ciudad Trujillo: Editorial del Caribe, 1955.

27

Sobre a captura e eventualmente 0 assassinato de marinheiros espanhóis, ver "El Gobernador Marqués de Someruelos da cuenta de haber apresado los negros de Santo Domingo un bergantin español y del cruel procedimiento que resulta tubieron con la tripulación" (16 de outubro de 1804), (AHN, Estado, leg.6366, exp.95; "El Gobernador Marqués de Someruelos instruye del apresamiento de un buque español por los negros rebeldes de Santo Domingo", 1804 (AHN, Estado, leg.6366, exp.100); Joseph Murillo a Someruelos (7 de outubro de 1804) (AGI, Cuba, leg.1648); e depoimento de Juan Bautista Faget (16 de abril de 1804) (AGI Cuba, leg.1648). Sobre a captura de navios negreiros por forças haitianas, ver "Oficio de la Junta Consular al Capitán General (26 de junho de 1811)" (Biblioteca Nacional José Martí [BNJM], CM Morales, t.79, n.26).

28

Sobre os rumores especificos de invasão, ver Manuel Guevara Vasconcelos, Capitán Gral. de Caracas, al Ministro de Estado (4 de janeiro de 1804) (AGI, Estado, leg.68, exp.3); "Carta reservada dirigida al Yntendente de la Habana, dando cuenta de los designios hostiles de los negros y mulatos de la parte francesa de Santo Domingo (19 de maio de 1818) (ANC, AP, leg.99, exp.101); Sebastian Kindelán al Sr Yntendente del Ejercito, 1822 (ANC AP, leg.113, exp.8); Comunicación del Comandante Militar de Baracoa al Gobernador de Santiago de Cuba pidiendo resfuerzos militares en vista de las amenazas de un ataque por parte de Haiti (30 de junho de 1823) (ANC, AP, leg.113, exp.104) Reservada, Carta n.2900, Ystancia de la alarma en que ha puesto a la República de Haití la misión del Intendente de Cuba Don Felipe Fernández de Castro [...], 1830 (ANC, Gobierno Superior Civi [GSC], leg.524, exp.18739); "Comunicación de

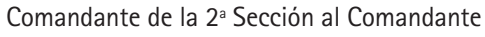
General del Departamento Oriental, Bayamo, dando cuenta de las disposiciones adoptadas en vista de temerse una invasión desde la república de Haití 1830)" (ANC, AP, leg.121, exp.23);

"Documento re. intención del gobierno de Haití de revolucionar esta Isla (18 de dezembro de 1830?)" (ANC, AP, leg.215, exp.89); do capitão general de Puerto Rico ao secretário de Estado (1830) (AHN, Estado, leg.6376, exp.31).

29

Comisión de Arango en Santo Domingo. In: Obras. Op. Cit., l, p.340-383. Para uma descrição como um único território, englobando toda a ilha, ou seja, indo substancialmente além de sua próspera capital - Havana - e seus arredores.

Embora o exemplo do Haiti focasse o olhar das elites em Cuba, os funcionários coloniais estavam em alerta constante para o desenvolvimento da situação em Santo Domingo e mesmo no Haiti. Funcionários que atuavam no leste de Cuba informavam sobre os refugiados que deixavam a colônia francesa durante a revolução, tanto no momento em que Dessalines proclamou a independência, em 1804, como quando dos conflitos internos da nova república, que trouxe novas ondas de migrantes, ainda que mais limitadas. ${ }^{25}$ Indivíduos repassavam as informações coletadas junto aos próprios correspondentes instalados em Saint-Domingue, Santo Domingo e áreas vizinhas. ${ }^{26}$ Depois da declaração de independência do Haiti, foram reportadas ameaças marítimas. Marinheiros espanhóis ou de outras nacionalidades desembarcavam nas praias cubanas dizendo que quase tinham sido capturados por negros haitianos, falando de compatriotas menos afortunados que tinham sido mantidos como escravos dos líderes negros ou haviam sido cruelmente mutilados nas mãos dos selvagens. Isso os fez prestar mais atenção às muitas oportunidades de captura dos navios negreiros com destino a Cuba por haitianos e a entrega de sua carga humana para as autoridades do Haiti. ${ }^{27} \mathrm{E}$ durante a primeira metade do século XIX, houve várias ondas de boatos e especulações sobre uma possível invasão de Cuba pelo Haiti, sobre tentativas de libertar os escravos cubanos ou encorajá-los à revolta e ao massacre.

Esses rumores eram precisos o bastante para que o Estado colonial enviasse periodicamente seus agentes ao Haiti, a fim de investigar a probabilidade de tais conspirações e, ao mesmo tempo, informar sobre 0 tráfico de negros e o comércio em geral. ${ }^{28}$ Uma das primeiras missões desse tipo foi realizada precisamente em 1803 por Francisco Arango y Parreño. Ele passou vários meses no Haiti e em Santo Domingo com seu escravo Felix, e receberam informações em primeira mão de um oficial francês mantido dois meses em cativeiro por escravos rebeldes. Em seguida, ele voltou a Cuba para escrever sobre a escravidão, o comércio e a política, com uma influência ímpar à época. ${ }^{29}$ Missões de espionagem no Haiti para ter certeza de suas intenções em relação a Cuba continuaram ao longo do século, e aumentaram depois da invasão do Haiti em Santo Domingo, entre 1822 e 1844, quando aquele território já se encontrava independente do controle espanhol. Depois, houve uma enxurrada de informações sobre a revolução em Saint-Domingue, mais tarde Haiti. Em Cuba, como demonstrou J. S. Scott a respeito das Américas, informações sobre o Haiti eram abundantes e variadas.

Apesar da variedade de fontes disponíveis, existem certas semeIhanças na forma como eram apresentadas as informações sobre os acontecimentos no Haiti. Pode-se observar, por exemplo, que mesmo se as referências explícitas ao Haiti tenham sido introduzidas pelos senhores, autoridades ou mesmo escravos, nem por isso deixavam de ser vagas, breves ou meramente alusivas. Quase sempre os refugiados que chegavam de barco eram objeto de uma descrição na qual eles declaravam que tinham fugido depois dos inevitáveis massacres inflingidos por Toussaint, Dessalines ou simplesmente "pelos negros". Mesmo as descrições de violência costumavam ser lacônicas e implícitas, referindo-se simplesmente à barbárie e selvageria dos negros e, muitas vezes, pedindo ao leitor que imaginasse a cena. Outras vezes, supunham que os detalhes podiam ser encontrados em 
da viagem, ver DOMíNGUEZ, Francisco Ponte. Francisco Arango y Parreño, el estadista colonial. Havana: Editorial Trópico, 1937. p.158-169. 0 informante francês de Arango parece ter sido Pascal Sabes, general de brigada (Calander of Rochambeau Papers, entrada 1699).

30

Sobre a "pirataria", ver ANDERSON, Benedict. Op. Cit.
Carta de Rafael Castillo ao governador de Santiago de Cuba (23 de junho de 1841). In: "La comisión dada por el gobernador de Cuba a D. Ramón Arango para adquirir noticias de Haiti e igual comisión a Dn. Rafael Castillo" (ANC, AP, leg.136, exp.26). outros relatos e se eximiam da tarefa de descrevê-los. Outros ainda afirmavam que os acontecimentos no Haiti foram acompanhados dos antigos pesadelos e previsões. Parecia haver uma linguagem própria para se falar do Haiti, um vocabulário da revolta, da agitação dos escravos, com um tom de apocalipse racial, que parecia estar ao alcance imediato de muita gente. Além disso, essa semiótica poderia ser distorcida: palavras e imagens circulavam e o recurso a elas se fazia sem a preocupação de se verificar ou de saber o que estava acontecendo no Haiti. ${ }^{30}$

Uma missão secreta ao Haiti, liderada por Rafael Castillo em 1841, mostra a maneira pela qual as suposições habituais sobre a ilha podiam ser relatadas enquanto informação, mesmo se todos os fatos parecessem desmenti-las. 0 relatório da missão notou não a força, mas a fraqueza do Haiti. Apesar das menções constantes ao poder do Haiti, à ameaça marítima contra o comércio negreiro e contra Cuba em geral, Castillo relatou que as fortalezas haitianas estavam vazias, suas tropas desarmadas, indisciplinadas e incapazes, e que muitas forças nem mereciam esse nome. Ele também escreveu, com evidente alívio, que "o espírito dos negros" não parece ameaçar Cuba. A Constituição haitiana assumiu uma posição claramente anti-intervencionista, dizendo que o Haiti não cometeria hostilidades contra os seus vizinhos sem provocação. E Castillo afirmou que não havia prova em contrário. Ele concluiu de forma inequivoca: "Eu não vejo, dessa maneira, nenhuma razão para ter medo ou perigo de qualquer espécie."

No entanto, apesar das evidências apoiarem sua conclusão, seu relatório, na sequência, adquire um tom dramaticamente diferente. Ele anunciou o perigo pelo simples fato de que o Haiti era o Haiti. Assim, tendo rejeitado a possibilidade de uma ameaça haitiana, Castillo profetizou que, um dia, a maneira de pensar do Haiti iria mudar "e que através de agentes disfarçados infiltrados em nossa terra - ainda virgem nesses males -, experimentaremos uma tempestade à qual talvez possamos sobreviver. Além disso, apesar do julgamento favorável que mencionei acima, [os haitianos] veem Cuba com desconfiança e inveja [...]. Por isso, temendo por minha própria segurança, decidi ir a Saint-Thomas" ${ }^{13}$. Ele alegou que não havia risco algum, mas sentia-se suficientemente em perigo para querer fugir. Ele afirmou que não havia necessidade de temer, e no entanto mencionou uma ameaça iminente, como se ela fosse certa.

0 Estado colonial fazia o mesmo, declarando acreditar em sua segurança, embora enviasse agentes secretos, reforçasse regularmente a costa e mantivesse contato próximo com indivíduos e autoridades no Haiti, em Santo Domingo, na Jamaica, em Porto Rico, em Saint-Thomas e, ao norte, até a Filadélfia. Ele monitorava de perto a atividade da ilha mas, para expressar seu medo de uma possivel ameaça, usava uma linguagem apocalíptica, de naufrágio ou de terror - discursos repetitivos baseados em sua opinião acerca do significado do que haviam sido o Haiti ou sua revolução.

\section{Escravos, escravidão e terror haitiano}

Os cálculos dos benefícios e perigos da escravidão no mundo após a Revolução Haitiana levaram o Estado colonial a prestar atenção não só na população de Cuba ou na política da ilha vizinha, mas também nas características da escravidão em si, notadamente nas relações entre senhores e escravos. Era comum descrever e relatar os acontecimentos no Haiti culpando os agricultores e os proprietários - não para desonerar os escravos, mas para negar a capacidade e o poder de ação deles. Houve uma 
Ver, por exemplo, "[...] Carta al Capitán General Someruelos [...], 1805" (AGI, Cuba, leg.1549 [nota 285]).

33

"Expendiente instructivo para suavizar la suerte de los negros esclavos" (ANC, RCJF, leg.150, exp.7405). Sobre a circulação desse relato, Manue Barcia, comunicação pessoal (julho de 1999).

34

KNIGHT, Franklin. Slave Society in Cuba during the Nineteenth Century. Madison: University of Wisconsin Press, 1970; RIVA, Juan Pérez de la. El barracón: Esclavitud y capitalismo en Cuba. Barcelona: Editora Crítica, 1978; ORTIZ, Fernando. Los negros esclavos. Havana: Revista Bimestre Cubana, 1916; e FRAGINALS, Manuel Moreno. El Ingenio. 3 Vols. Havana: Editorial de Ciencias Sociales, 1978.

35

Diz-se que isso aconteceu na fazenda de Serapio Recio em Santa Cruz, Puerto Príncipe, 7 de junho de 1795. Carta ao capitão general (14 de junho de 1795), "Correspondencia del oficio del Teniente Gobernador de la Villa de Puerto Príncipe D. Alfonso de Viana con la Capitanía General sobre negros, su expulsión y levantamientos" ("Expediente relativo a las precauciones y seguridad...", ANC, RCJF, leg.209, exp.8993). tendência a condenar os senhores por duas razões (por vezes contraditórias): primeiro, eles foram acusados de serem demasiado liberais, de ter ensinado aos escravos as idéias que pavimentaram o caminho da revolução. Os agricultores também foram acusados de serem duros e brutais e, assim, provocar a ira. 0 comportamento dos proprietários era tão controverso que os funcionários coloniais passaram a espioná-los para garantir que eles não incentivassem seus escravos a conspirações, rebeliões ou qualquer outra ameaça à colônia. Conscientes de que esse monitoramento podia dar aos escravos uma sensação de poder sobre os senhores, as autoridades advertiram que os escravos nada deviam saber a respeito dessas inspeções. ${ }^{32}$

No clima que reinou em Cuba após a Revolução Haitiana, as pessoas não só ouviam falar da miséria e decadência de Saint-Domingue, como também conheciam as histórias locais acerca das estratégias e ações de senhores e escravos na própria ilha. Assim, a história que inspirou, em 1976, o famoso filme cubano "La ultima cena", do diretor Tomás Gutiérrez Alea, soou como um aviso. Tratava-se de um senhor que, observando os preceitos da Páscoa, lavou os pés de doze de seus escravos; em seguida, convidou-os a sentar-se em sua mesa, e se viu recompensado com a rebelião desses mesmos escravos que ele tratara como apóstolos. A lição parece clara: questionar o lugar dos escravos, a partir de uma perspectiva cristã ou de uma concepção republicana revolucionária, era um convite à revolta e um estímulo à resistência. ${ }^{33}$

Mas poucos senhores estavam lavando os pés de seus escravos ou repetindo publicamente slogans republicanos, e poucos escravos comiam à mesa deles. Na verdade, aqueles que tinham experimentado o mesmo comportamento selvagem observado entre os senhores de Saint-Domingue eram mais numerosos. 0 rápido desenvolvimento da economia açucareira acabou privando os escravos de usufruir de suas roças, alongou as jornadas e as semanas de trabalho e tornou mais severos os castigos que acelerariam o ritmo de trabalho ou corrigiriam a alegada insolência que os brancos viam em todos os lugares desde a Revolução Haitiana. ${ }^{34}$

Assim, na Cuba pós-Haiti, as relações entre senhores e escravos se estabilizaram em um contexto no qual a escravidão ascendia, o crescimento econômico levava a uma demanda maior por trabalho e as informações sobre a Revolução Haitiana circulavam entre os escravos e os senhores, que informavam as autoridades locais sobre o conhecimento que os escravos tinham acerca dos eventos em Saint-Domingue. Os agentes transmitiam informações às autoridades da ilha e da metrópole. Relatavam incidentes classificados como de insolência. Falavam de escravos que se opunham aos seus senhores, recusando os maus tratos, proclamando a igualdade de todos, profetizando a humilhação dos brancos e atacando fisicamente seus senhores. ${ }^{35}$ "Com expressões dignas de um homem ignorante dominado por princípios fúteis, mas sediciosos", semelhantes às dos escravos do fazendeiro Fernando Rodriguez, lembraram às autoridades e aos senhores que "negros franceses tinha conquistado sua liberdade". Diante de tais informações, as autoridades insistiram na necessidade de conter a repercussão do Haiti e remover os escravos estrangeiros, proibindo qualquer reunião de negros ou gente de cor, exercendo uma vigilância forte e constante e distribuindo os castigos que julgassem necessários. No caso do escravo de Rodriguez, o vice-governador o condenou a cem chibatadas, pendurando em seu pescoço um cartaz com uma inscrição para que os outros vissem: "Este é o fruto da liberdade concebida pelos escravos franceses. A verdadeira 
"Viana ao capitão general" (9 de abril de 1796), ibidem

37

Pesquisas pessoais em curso sobre a veracidade desses presumidos incidentes. Para uma lista e uma discussão das conspirações e rebeliões nas ilhas caribenhas desde o período próximo à revolução do Haiti até 1815, ver GEGGUS, David Patrick. Slavery, War and Revolution in the Greater Caribbean. In: GASPAR, David Barry e GEGGUS, David Patrick. (eds.). A Turbulent Time:The French Revolution and the Greater Caribbean. Bloomington: Indiana University Press, 1997. p.1-50.

38

Para uma discussão sobre como o rótulo "revolta de escravos" tem sido usado de forma abusiva por historiadores e contemporâneos, ver GEGGUS David Patrick. Slavery, War and Revolution... 0p. Cit., e THORTON, John K. Africa and Africans in the Making of the Atlantic World, 1400-1800. Cambridge: Cambridge University Press, 1998. p.300-301. Para uma discussão sobre como esse uso pelos fazendeiros e pelo Estado justificou as respostas de "terrorismo racial", ver JOHNSON, Walter. Possible Pasts: Some Speculations on Time, Temporality, and the History of the Atlantic Slave Trade. Amerikastudien/American Studies, n.45, p.485-499, 2000. Ver também APTHEKER Herbert. American Negro Slave Revolts. Nova York: International Publishers, 1963, cap.7, e WALVIN, James. Questioning Slavery. Londres: Routledge, 1996. p.121.

39

"Noticias acaecidas en la Villa de Puerto del Príncipe el día 12 de junho de 1798". In: "Expediente relativos a las precauciones y seguridad [...]" (ANC, RCJF, leg.209, exp.8993).

40

"Relación de los conatos de levantarse en armas los negros esclavos de la jurisdicción de Camagüey". In: ARREDONDO, F. de. "Relació de los acontecimientos políticos occurridos en el Camagüey" (BNJM, CM Arredondo, n.8).

41

AVELLANEDA, Gertrudis Gómes de. Autobiografía y epistolarios de amor. Ed. por Alexander Roselló Selimov. Newark: Juan de la Cuesta, 1999. p.51. liberdade está na virtude" ${ }^{136}$. Em Cuba, como no restante do mundo atlântico, ficou claro que os escravos tinham conhecimento dos fatos ocorridos em Saint-Domingue e que essa consciência e esse exemplo levaram alguns deles a fazer alegações inimaginável alguns anos antes.

Os brancos repetiam que a Revolução Haitiana tinha tornado os escravos locais suspeitos e propensos à rebelião, o que os arquivos parecem confirmar. Nas décadas seguintes à eclosão da rebelião no Haiti, alegou-se a existência de dezenas de conspirações e revoltas em Cuba. De fato, a principal razão pela qual os estadistas e líderes não foram totalmente seduzidos pela vontade de imitar Saint-Domingue talvez tenha sido a onda de resistência e rebelião que parecem ter nascido da era pós-revolucionária no Haiti. A natureza e a extensão desses desafios frente à condição dos escravos pareceram alarmantes. Em intervalos regulares, ocorreram atos de violência maiores ou menores contra os feitores, os senhores, as autoridades ou os brancos em geral. Assim, a região de Puerto Príncipe, que experimentara uma significativa migração da parte espanhola da ilha depois que a mesma foi cedida aos franceses em 1795, e mais tarde ocupada por Toussaint Louverture, em 1801, foi palco de conspirações e revoltas abortadas em 1795, 1797, 1798, 1799, 1805, 1809 e 1811-1812. ${ }^{37}$ Por causa da freqüência das desordens, sem dúvida era mais difícil para as autoridades e os comerciantes de Havana divulgar a ideia de que o medo não tinha fundamento.

Embora a natureza e a extensão do movimento dos escravos fossem muito diferentes, as descrições dos oficiais brancos usavam o mesmo vocabulário. Primeiro, eles se referiam a todos esses acontecimentos como revoltas: em alguns casos, eram pouco mais do que conversas clandestinas de um punhado de escravos; ou incidentes de fugas - em vez de luta - de pequenos grupos de escravos de uma propriedade.$^{38}$ Mas o vocabulário compartilhado por fazendeiros e autoridades ia além do rótulo de revolta. Os observadores também falavam com confiança de planos de supostos rebeldes, mesmo quando as evidências não permitiam tais conclusões. As autoridades relatavam histórias de bandos de negros gritando "Morte aos brancos! Morte aos brancos!" ou sobre as intenções dos negros de matar todos os brancos e reservar as mulheres brancas para o seu "uso" e (mais frequentemente) sobre "tantas coisas assustadoras de se ouvir"39. Na maior parte do tempo, a comparação com Saint-Domingue era explícita. Nos rumores e ecos de rebelião ou conspiração, as referências ao Haiti circulavam: os rebeldes queriam seguir o exemplo dos escravos franceses; Cuba não tem que conhecer esse tipo de revolta que destruiu a bela ilha francesa de Saint-Domingue, etc. As referências eram vagas, mas constantes. Em Puerto Príncipe, onde havia rumores de uma possivel revolta no Natal de 1809, o governo lembrou que "todos temiam uma súbita explosão semelhante à de Saint-Domingue, um exemplo relatado com a mesma paixão para as senhoras" 40 . 0 pai da famosa romancista do século XIX, Gertrudis Gómez de Avellaneda, previra "para Cuba um destino semelhante ao da ilha vizinha, pela mão dos negros", e pediu à sua mulher que fosse com ele para a Espanha. ${ }^{41}$

De fato, senhores, autoridades e outros observadores brancos talvez tenham sido muito rápido em ver semelhanças nos projetos. Isso não chega a surpreender: a importância e a natureza do Haiti tinham conquistado a imaginação deles. Era difícil não perceber isso a todo instante, em uma sociedade onde os escravos e gente livre de cor recentemente tinham ultrapassado o número de brancos e onde as manifestações de descontentamento e rebelião pareciam tão frequentes. Mas ver todo o potencial do 
42

O'Farill, López e Patrón ao comandante de Santa Clara (18 de agosto de 1798). In: "Expediente relativo a las precauciones y seguridad" (ANC, RCJF, leg.209, exp.8993). Enquanto os abolicionistas ingleses e os missionários intensificaram sua propaganda, referências aos riscos causados pelos escravos ingleses também começaram a aparecer.
43

ANC, AP, leg.9, exp.27. 0 documento original está danificado. (Agradeço a Pedro Guibovich pela ajuda na transcrição.) Aqui está o que eu interpreto como uma referência ao Haiti: "[...] que quedarían asolutos y livres como el Gua [...]". 0 dossiê sobre a rebelião é "Expediente criminal contra Francisco Fuertes y dema's negros [...] sobre levantamiento en el pueblo de Güines, 6 de Mayo de 1806".

44

0 original está bastante desarticulado. "Los preparativos demuestran el liberado ánimo y las atrosidades que debian resultar de esta empresa [si no se] hubiera descubierto oportunamente [...] se ve que era bastante arduo [...] con el plan concertado [...] haverse evitado los mas sangrientes sucesos" (p.222-227)
Haiti em Cuba também podia ter outro significado: considerar qualquer resistência local (ou apenas a possibilidade de resistência) como fruto de uma influência haitiana demonstra que os problemas não eram estruturais ou relacionados à escravidão em si, mas conjunturais, causado por um acidente no Haiti. Foi também uma forma de negar a capacidade de ação dos escravos em Cuba. Um oficial, referindo-se à freqüência das revoltas recentes (cinco em menos de três anos) e aludindo à presença óbvia de escravos franceses e ingleses, destacou que os dois acontecimentos estavam intrinsecamente ligados. Os escravos estrangeiros, disse ele, "eram experientes na prática da insurrreição [que] não só contamina nossos escravos, mas também os inspira a criar suas próprias aspirações, ideias que até mesmo os mais indisciplinados eram incapazes de conceber" ${ }^{\prime 2}$.

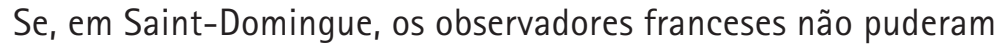
prever os acontecimentos de 1791 sem se referir aos agitadores não-escravos, em Cuba os fazendeiros e estadistas não eram capazes de considerar seus próprios escravos como artífices de um movimento conspiratório ou de resistência. E, nesse contexto, o Haiti tornou-se o "agitador externo" por excelência.

Isso não quer dizer que a Revolução Haitiana não teve impacto sobre os escravos cubanos, ou que essa influência tenha sido exagerada, mas sim que a inspiração ligada à sua imagem, ao seu nome e à sua revolução não podem ser tomadas ao pé da letra como sinais ou propostas relacionadas a ela. Formas locais de conspiração, rebelião e resistência, mesmo que inspiradas pela Revolução Haitiana e pelo "clima geral de conflito" que tanto marcaram o mundo atlântico na era da revolução, eram muito mais complexas do que poderiam sugerir as simples referências ao Haiti. A evocação desta ilha por senhores, escravos e homens de Estado não necessariamente se referem às influências externas, mas talvez fossem, acima de tudo, uma chave de leitura para explicar as circunstâncias imediatas e locais. Era uma imagem, a apropriação de um nome para pedir a liberdade ou para restaurar a ordem, de acordo com o orador que a utilizasse. Por sua invocação constante, o Haiti tornou-se uma força local.

Foi assim na suposta conspiração de escravos em Guines, na província de Havana, em 1806. Três escravos revelaram a existência de um complô para colocá-los contra seus proprietários e andar pela cidade vizinha de Guanabacoa matando homens, mulheres e crianças brancos pelo caminho, apossar-se da cidade e estabelecer uma "liberdade absoluta como em Guarico"43. Quando a notícia de uma possível trama se espalhou, foi imediatamente associada ao Haiti. 0 testemunho dos escravos, envolvidos ou não, refere-se constantemente à liberdade e à Revolução Haitiana. A correspondência das autoridades enfatizou a influência dos escravos haitianos e afirmou, de forma inequívoca, que se a conspiração tivesse se materializado, desferiria um golpe fatal. No decurso do inquérito, elas mantiveram a discrição, para evitar que a notícia chegasse aos ouvidos das pessoas de cor "ou mesmo dos brancos", e tentaram dar a impressão de que o incidente foi "de menor importância" (p.49). Um ano e meio depois da descoberta da conspiração, as autoridades concluíram: "Os preparativos evidenciam o espírito arrojado e as atrocidades que resultariam dessa tentativa, se não fosse descoberta a tempo [...]. Ao que parece, era um plano muito bem montado [...]. As cenas sangrentas foram evitadas"44.

Portanto, a certeza com que eles entreviam a possibilidade, logo comprovada, de derramamento de sangue e de uma explosão, não parece 
45

0 aumento foi contínuo depois disso, já que a região tinha 47 engenhos de açúcar em 1827 e 66 em 1846 (FRAGINALS, Manuel Moreno. $E$ Ingenio. Op. Cit. Vol.1, p.140). Os números de MARRERO, Levi. Cuba: economia y sociedad, Madri, são um pouco diferentes: oito usinas em 1796, 26 em 1800. Sobre a revolução do açúcar em Guines, ver FRAGINALS, Manuel Moreno. El Ingenio. Op. Cit. Vol.1, p.57-62.

Ibidem, p.58 e p.110. Ver também MARRERO, Leví. Op. Cit. Vol.10, p.VI-VII (ilustração e descrição do engenho Amistad). justificada pelos projetos dos pretensos rebeldes. Os testemunhos, neste caso, são inconclusivos. Há confissões e negações, referências a declarações feitas sob a influência do álcool ou da sedução por bons oradores. De acordo com os depoimentos, o plano dos rebeldes era vago e confuso. Houve uma clara discordância sobre os métodos a empegar, e o grau de apoio e consenso entre os escravos da região não parece particularmente impressionante.

Embora os testemunhos sobre o complô em si pareçam inconclusivos, as autoridades viram nas declarações dos escravos claras evidências de seu desejo de revolta, ou pelo menos, expressões do descontentamento deles. As declarações dos escravos constantemente mencionavam a brutalidade, o desespero, o cansaço; e essas referências explícitas à dureza da sua condição também pareciam confissões convincentes da aspiração deles à liberdade e da atração irresistivel para fazer deslanchar um outro Haiti. Mesmo os escravos que negaram envolvimento, e mais ainda aqueles que tinham traído os planos da revolta, explicaram sua recusa em se rebelar em termos que não deixavam dúvidas do descontentamento que sentiam. Eles foram mantidos fora dos planos insurrecionais não porque queriam evitar a revolução, mas porque tinham constituído famílias que não queriam pôr em perigo, ou porque sentiam que eram poucos, despreparados e sem recursos para vencer uma batalha contra os brancos e os proprietários.

Teoricamente, se não na prática, era óbvia a atração da Revolução Haitiana para a maioria dos escravos que prestaram depoimento. Não é tão surpreendente que o Haiti estivesse presente nos testemunhos dos escravos e nas preocupações das autoridades. 0 exemplo e a imagem da ilha, a linguagem da liberdade dos negros e de um apocalipse racial circulavam continuamente no mundo atlântico. Porém, nesta parte remota da província de Havana, a referência provavelmente teve um significado especial, porque foi na região de Guines que as transformações que fizeram de Cuba uma nova Saint-Domingue foram mais claras e numerosas.

Guines era uma região fértil, de terra roxa, rica em sais minerais. Localizada a uns trinta quilômetros a sudeste de Havana, tinha sido por muito tempo o principal enclave do cultivo de tabaco por pequenos agricultores. A partir de fins da década de 1780 e ao longo da década de 1790, estes pequenos agricultores tinham sido quase completamente substituídos, por vezes em processos violentos, pelos plantadores de açúcar e suas grandes propriedades. Foi nesse fértil vale do Guines que a indústria açucareira de Cuba começou a crescer, após os eventos em Saint-Domingue. Ali foram erguidos quatro engenhos de açúcar em 1784, nove em 1792 e 26 em 1804, apenas dois anos antes da conspiração. ${ }^{45}$ Mas a revolução do açúcar em Guines significou mais do que apenas a multiplicação do número de engenhos. A área também podia se orgulhar de possuir a maior e mais avançada tecnologia, que estava nas mãos dos homens mais poderosos da ilha. Quando Luis de las Casas, o novo capitão geral, chegou a Havana proveniente de Madrid em 1790, os plantadores deram a ele uma propriedade em Guines. Ali também se situava Ninva, a propriedade de Francisco Arango y Parreno, que foi por muito tempo a maior propriedade açucareira de Cuba e do mundo. As propriedades do presidente, do síndico, prior, consul e conciliaro do Real Consulado estavam todas em Guines. Técnicos vindos de Saint-Domingue que haviam fugido da revolução e do colapso da indústria na colônia francesa estavam diretamente envolvidos na criação dessas fazendas. ${ }^{46}$ A intensificação da produção regional de açúcar foi acompanhada por um aumento no número de escravos para trabalhar nos estabelecimentos 
47

BERGAD, Laird, GARCIAA, Fe Iglesias e BARCIA, Maria del Carmen. The Cuban Slave Market, 1790-1880. Cambridge: Cambridge University Press, 1995. p.27.

48

MARRERO, Leví. Op. Cit. Vol.9, p.217 e 221. Ver também: "Resumen general de los moradores que comprehende el Partido de Guara en todo el año de 1799" ("Expendiente instruido con objeto de fomentar la población blanca de esta Ysla", ANC, RCJF, leg.184, exp.8324). A população do distrito de Guara, que seria o centro da conspiração, dividia-se da seguinte forma: 304 brancos, 266 escravos negros, 4 escravos mulatos, 4 negros livres e 6 mulatos livres.

49

A vasta literatura sobre as formas de resistência

e as revoltas de escravos nas sociedades escravistas do Novo Mundo as qualificam de "africanas", "restauradoras", "criolas", etc. Estas tentativas de classificação as interpretam como episódios mais amplos de transformação política e cultural no interior das histórias. Para GENOVESE, Eugene. Op. Cit., essa transformação variou de rebeliões africanas e restauradadoras até a revolução burguesa ou crioula - uma transformação que data das revoluções francesa e haitiana e, para ele, marca a entrada de escravos negros na história moderna e do mundo. Michae Mullin e Michael Craton também argumentaram a favor de uma transformação na natureza e na forma das rebeliões, algumas claramente "africanas" no início da história do mundo atlântico; outras, crioulas, mais adentradas no século XIX. Eles vêem as transformações culturais entre os africanos escravizados, que se tornaram cada vez mais americanos, crioulos ou negros (MULLIN, Michael. Africa in America: Slave Acculturation and Resistance in the American South and the British Caribbean, 1736-1831. Urbana: University of Illinois Press, 1992; CRATON, Michael. Testing the chains: Resistance to Slavery in the British West Indies. Ithaca: Cornell University Press, 1982 agrícolas e industriais mais importantes da ilha. Na verdade, de todos os escravos importados para Cuba na época, uma proporção significativa destinava-se às florescentes propriedades da província de Havana. ${ }^{47} \mathrm{Em}$ 1775, quase três quartos da população de Guines era classificada como branca, mas em 1817, a maioria era composta de escravos negros e os brancos representavam menos de $38 \% .{ }^{48}$ Guines passara por mudanças rápidas e profundas durante a década anterior à conspiração. Além disso, a população local conhecia bem a história de Saint-Domingue: os detentores do poder eram homens bem informados e que deliberadamente tentaram reproduzir Saint-Domingue. Os especialistas na produção de açúcar viviam no local cercados por escravos que viriam a se tornar rebeldes. $E_{1}$ sugere o projeto da conspiração, seus escravos eram homens e mulheres que conheciam a triunfal e violenta exigência de liberdade ocorrida em Saint-Domingue.

0 primeiro conspirador acusado e capturado pelas autoridades foi Mariano Congo, um escravo nascido na África e de idade indeterminada que, em um domingo, foi ao ingenio Concordia, onde quis recrutar três outros escravos do Congo - Joaquín, Marcelino e Toribio. Estes revelaram a trama a seus senhores; Mariano foi capturado pouco depois de sua chegada e colocado a ferros. Sua prisão deu origem a uma grande investigação sobre a suposta conspiração. Os três homens que a revelaram foram interrogados, além de Mariano. 0 mesmo aconteceu para todos os escravos que mencionei. As quinhentas páginas de depoimentos e correspondências revelam o esboço não de uma conspiração mal planejada, mas o início dela. Quando foram descobertos, os líderes ainda estavam procurando recrutar companheiros. 0 plano deles era simples: queriam que os escravos das propriedades locais de açúcar e café se revoltassem, armados com paus e pedras, e depois marchassem até a cidade de Guanabacoa, recolhendo armas e munições no caminho. Mas não houve acordo sobre os objetivos da marcha. Alguns queriam matar todos os brancos que encontrassem pelo caminho, enquanto outros pretendiam salvar sacerdotes, ou alguns senhores e senhoras, e colocar as crianças na prisão (em vez de matá-las). Houve um consenso mais amplo sobre o que poderia resultar de uma marcha vitoriosa: eles assumiriam o controle do Forte de Guanabacoa e ficariam em "total liberdade".

0 projeto da revolta parece ter surgido entre os escravos de Esteban Alfonso, que era ao mesmo tempo fazendeiro e funcionário da administração local. Mariano Congo, o primeiro a ser preso e que, sem dúvida, era integrante da conspiração, parece ter sido o terceiro homem na hierarquia, não o líder. De fato, dois de seus companheiros de infortúnio tinham elaborado a trama de se rebelar para ganhar a liberdade. Um deles era Francisco Fuertes, um escravo crioulo nascida em Cuba; o outro, Estanislao, era um escravo francês vindo da ilha vizinha havia vários anos e que tentava engajar seus companheiros para tomar parte na revolução negra. Os três escravos eram os mais envolvidos na conspiração e, embora pertencessem ao mesmo senhor, eram diferentes em pelo menos um aspecto importante. Um era africano, o outro era crioulo e o terceiro era haitiano, tipos-ideais geralmente associados a diferentes "categorias" de revoltas de escravos: africana ou restauradora, crioula ou burguesa revolucionária. ${ }^{49} \mathrm{~A}$ colaboração entre eles sugere que olhemos para além desses rótulos, a fim de saber como resistência e rebelião podiam inspirar-se simultaneamente em tradições e motivações múltiplas. Os depoimentos de escravos a respeito de uma série de incidentes em Cuba fazem referências a protagonistas 
africanos, crioulos e caribenhos, às danças ritmadas ao som de tambores e búzios, com um possível sacrifício de porcos. Apresentando-se como um membro da grande raça das Índias ou expressando seu desejo de tomar a terra dos brancos, podemos ler estas ações e declarações como sinais de uma "dimensão africana", ou como evidência de uma identidade crioula emergente, ou ainda como referências às reivindicações e ações dos rebeldes haitianos. Se o esquema acadêmico tenta inscrever a resistência dos escravos nos relatos europeus mais amplos sobre a revolução e a modernidade, a crioulização e a desafricanização, ou colocá-las em contato com a influência das políticas imperialistas europeias, isso levou as interpretações a tentar dar conta das ações e proclamações dos rebeldes como ações de grupos limitados ou comunidades maiores, e compreender a referência ao Haiti, em particular os rumores e apelos à rebelião, as ameaças e a vigilância por parte dos senhores e seus empregados, ou o desejo de se proteger, e às suas famílias, em tempos considerados difíceis por todo o mundo.

Nesta época conturbada, os escravos de Guines viviam e trabalhavam em uma agricultura próspera, onde a produção aumentou de forma constante e as exigências do trabalho e de ordem se tornaram cada vez mais prementes. Assim, quando os supostos líderes e seus companheiros escravos foram questionados, não parece ser este conjunto de circunstâncias que eles levaram em conta para explicar a conspiração. Muitos declararam que Estanislao, o escravo haitiano, tinha proclamado que chegara a hora, que eles estavam cansados de trabalhar, que não podiam mais suportar os brancos e que era hora de matá-los. Muitos escravos que recusavam o chamado à revolta confidenciaram que suas jornadas de trabalho eram implacáveis, que não lhes deixava tempo para trabalhar em seus lotes de terra, que eles não recebiam instrução religiosa ou cuidados e que a disciplina era muito severa.

Em sua lista de queixas, a mais recorrente e importante dizia respeito à severidade das punições corporais. Pouco antes da tentativa de levante, outro escravo, Bernardo, havia se suicidado. Ele tentara fugir e, após sua captura, fora espancado violentamente e, em seguida, colocado a ferros. No dia seguinte, foi obrigado a trabalhar, mesmo tendo passado por tudo aquilo. Exausto, como disseram seus companheiros, enforcou-se em uma árvore. 0 suicídio ocorreu logo após a morte de vários escravos da propriedade, atribuídas aos maus tratos físicos: Rafael morreu depois de receber uma punição que na Jamaica era chamada de "dose de Derby", que consistia em obrigar os escravos a comer excrementos humanos; Maria del Rosario e outra negra anônima, doente, foram presas e mortas em um poleiro; Pedro Carabali, espancado até a morte a cacetadas e lançado ao fogo, e Joseph Mandinga, criollito de sete anos de idade, morreram em consequência de punições não especificadas. A causa da conspiração podia residir nas condições descritas nestas declarações. Tanto é assim que as autoridades, ao investigar a conspiração dos escravos, também começaram a questionar a conduta de seu proprietário, Alfonso Esteban. 0 líder haitiano Estanislao, perguntado se sabia que o levante "dos inferiores contra seus superiores, especialmente quando incluiu assassinatos e outras crueldades", era um dos crimes mais graves, respondeu sem vacilar que sabia. Mas, disse ele, sua miséria, sua condição e "o tratamento que ele sofreu nas mãos de seu senhor o levaram a planejar coisas incriveis, para tentar melhorar sua sorte e aliviar o fardo da escravidão". Aqui podemos lembrar a afirmação lapidar de Herbert 
51

A respeito de reivindicações similares, em outra conspiração, ver o depoimento de escravos em 1793 em Hincha, Santo Domingo, em "Autos seguidos sobre la insurrección pretendida por los negros esclavos en Hincha" (ANC, AP, leg.4, exp.43).
As condições reais claramente influiram na articulação da revolta dos escravos de Guines. Mas o Haiti, seu precedente, sua imagem, sua própria existência, tornou-se uma de suas condições possibilitadoras. Seu nome era constantemente mencionado. As autoridades sugeriram que haviam impedido um novo Haiti; enfatizaram as origens haitianas de seus líderes e lamentaram a recusa dos proprietários locais em cumprir as leis que proibiam a posse de escravos franceses. 0 Haiti foi mais evocado pelos escravos. Estanislao, ele próprio um haitiano e uma das principais figuras da conspiração, era constantemente mencionado por suas tentativas de recrutar simpatizantes entre seus pares. Falou de sua pátria e parece ter sugerido a seus companheiros que ele tinha participado da revolução (o que negou diante dos juizes). 0 interesse da revolta, disse ele, era conquistar a liberdade, como no Haiti. Enquanto alguns escravos hesitavam, 0 crioulo Francisco Fuertes e ele insinuaram que seus irmãos haitianos pelo menos buscaram uma chance. Da mesma forma, eles não tinham armas ou meios, mas armaram-se com paus e pedras e conquistaram sua liberdade. Aqui, o Haiti foi invocado como um desafio: se os escravos franceses tiveram a coragem de se rebelar, por que não eles? ${ }^{21}$ Mas o Haiti era mais do que isso: era também um sonho. Quando o crioulo Francisco Fuertes foi recrutar escravos na área de Concordia, ele disse:

\footnotetext{
Compañeros, vocês conhecem, desde que trabalham neste engenho faz tempo, as dificuldades e os castigos a que os brancos nos submetem. Eu só vos digo que nós devemos recrutar e persuadir os negros de todas as plantações de café de Guira de Melena, assim como os negros de Don Pablo Esteves, os de Garzón, El Navío e de todos os engenhos de açúcar a subir na segunda-feira para matar todos os brancos e submeter ao suplício do garrote todas as crianças, tomar todas as armas e os cavalos, e acabar com os brancos". Ele disse que sairiam livres como em Guarico. Na verdade, houve uma longa discussão sobre o Haiti entre os escravos, disse um dos que tentou recrutar. Ele falou da revolução, da grandeza dos seus compañeros, do feito que eles tinham realizado, e que agora eles eram os "senhores absolutos" do Haiti.
}

Aqui, a referência ao Haiti claramente se relacionava à revolução. Revela a atração contínua exercida pela liberdade e um profundo respeito para com os rebeldes haitianos, seus companheiros de miséria. Mas o nome também foi usado como um argumento para criticar suas próprias condições de vida em Cuba. Novamente, isto não significa diminuir ou exaltar o impacto da Revolução Haitiana sobre os escravos locais, mas acentuar o fato de que sua influência potencial se desenvolveu no contexto de vida cotidiana em certas propriedades específicas, nas interações cotidianas entre senhores, empregados e escravos. As referências ao Haiti podiam tanto se relacionar com experiências cotidianas concretas como aos ventos da revolução no Atlântico. 0 Haiti podia ser invocado por estadistas e fazendeiros para defender a necessidade de ampliar o tráfico de africanos, o imperativo dos programas de imigração branca, a necessidade de segurança costeira, etc. Sem dúvida, ele também seria usado pelos escravos para afirmar sua dignidade vis-à-vis outros escravos, manipular o medo dos senhores brancos, as queixas pontuais e urgentes, ou talvez para tentar imaginar um mundo sem brancos, sem escravidão.

É bastante provável que os escravos imaginassem tal lugar há muito tempo. Senhores e homens de Estado agora acreditavam que os escravos tinham sempre em mente o exemplo do Haiti. Os acontecimentos no Haiti modelaram a forma como escravos e senhores passaram a ver uns aos 
outros e a considerar sua situação e seu futuro. Eles mudaram a forma de se referir às punições, expressando em voz alta seu desprezo, compreendendo seu próprio poder ou impotência.

Voltando à nossa observação inicial, sobre o silêncio em torno da Revolução Haitiana, trata-se de uma boa metáfora. Havia certamente muitos mal-entendidos - ou melhor, uma cegueira voluntária - sobre a revolução, naquele tempo como agora. No entanto, esta falta de compreensão não impediu que os olhares se voltassem ao Haiti a fim de refletir, dar sentido às intuições vagas, personificar a liberdade ou a catástrofe. Não que as informações sobre a revolução produzissem automaticamente o terror entre os brancos e a esperança entre os negros e os homens livres de cor. 0 Haiti expressava, sim, a frustração, o medo e a esperança. Aqueles que não pertenciam ao Haiti viveram também a história de sua revolução, invocando-a constantemente, manipulando-a, imaginando-a para seus próprios fins. Assim, Haiti tornou-se, antes mesmo de sua existência oficial, em janeiro de 1804, um símbolo polivalente que permitiu a escravos, senhores e agentes da Coroa fazer referências a visões divergentes do futuro. Para entender a história da revolução e seu impacto fora do Haiti, é preciso considerar a conscientização que a revolução provocou entre escravos em sociedades como Cuba, onde o Haiti foi tanto um modelo de sociedade escravocrata como um símbolo de liberdade. 